\title{
Persepsi Mahasiswa PBI terhadap Penerapan Pembelajaran Aktif Menggunakan Model Pembelajaran Kooperatif pada Mata Kuliah Drama, Prose, Poetry
}

\author{
Astry Fajria \\ Universitas Ahmad Dahlan \\ astry.fajria@pbi.uad.ac.id
}

\begin{abstract}
Literary subjects are usually presented through lecturing the students in the classroom, leading them into a stage of boredom. Conversely, learning method has shifted from teacher-centered to student-centered. This way, active learning becomes necessary. The study aims to know the students' perception on the use of active learning, especially cooperative learning, in Drama Prose Poetry subject. The research belongs to descriptive qualitative study, using closed and open questionnaires to obtain qualitative and quantitative data. The participants are 83 students taking Drama Prose Poetry subjects in the department of English Education. The results show that more than half of the participants (58 in number) agree to be more active in the classroom. Four types of cooperative learning methods are applied in the study: gallery walk, jigsaw, information gap, and drawing. Among the four activities, most students chose gallery walk as their favorite (53 in number).
\end{abstract}

Keywords: perception, active learning, drama, prose, poetry

Intisari

Materi mata kuliah sastra biasanya disampaikan melalui metode ceramah yang rentan menimbulkan kebosanan. Pada kenyataannya, metode pembelajaran telah beralih dari teachercentered menjadi student-centered. Dengan demikian, pembelajaran aktif diperlukan. Penelitian ini bertujuan untuk mengetahui persepsi mahasiswa terhadap penerapan pembelajaran aktif, terutama pembelajaran kooperatif, pada mata kuliah Drama Prose Poetry yang diwajibkan untuk mahasiswa semester IV Pendidikan Bahasa Inggris Universitas Ahmad Dahlan. Penelitian ini termasuk penelitian deskriptif kualitatif dengan menggunakan kuesioner tertutup dan terbuka untuk mendapatkan data kualitatif dan kuantitatif. Respondennya adalah 83 mahasiswa Pendidikan Bahasa Inggris semester IV yang mengambil mata kuliah Drama Prose Poetry. Hasil penelitian menunjukkan bahwa lebih dari separuh responden (58 responden) lebih suka belajar secara aktif di kelas. Empat macam kegiatan pembelajaran aktif diterapkan untuk mengetahui persepsi mahasiswa: gallery walk, jigsaw, information gap, dan drawing. Di antara keempat kegiatan, sebagian besar mahasiswa memilih gallery walk ( 53 responden).

Kata kunci: persepsi, pembelajaran aktif, drama, prosa, puisi 


\section{Pendahuluan}

Sastra merupakan cabang ilmu humaniora yang sarat makna dan nilai. Pembelajaran sastra asing, khususnya sastra Inggris, bisa memperkaya pengetahuan budaya dan bahasa peserta didik, terutama yang mengambil jurusan pembelajaran bahasa inggris, baik sastra inggris maupun pendidikan bahasa Inggris. Melalui tiga genre karya sastra, yakni drama, prosa, dan puisi, para sastrawan menuangkan perasaan dan pikirannya dengan bahasa yang indah. Melalui karya sastra, peserta didik, terutama mahasiswa pendidikan bahasa inggris, bisa mendapatkan hiburan sekaligus juga mendapatkan makna dan nilai kehidupan yang ditampilkan, baik dari karakter, tema, latar tempat dan waktu, maupun pengarangnya. Dari ketiga genre ini, pembaca, khususnya mahasiswa, bisa mempertajam empati sekaligus memperkaya kebahasaan mereka. Karya sastra yang ditulis dalam bahasa asing, khususnya bahasa inggris, memberi input kosakata yang beragam pada mahasiswa. Mereka tidak hanya mengambil pesan moral yang terkandung dalam karya sastra, tetapi juga bisa menerapkan kosakata asing baru yang mereka temui. Dengan demikian, semakin banyak mereka membaca karya sastra, semakin banyak sumber informasi yang mereka dapatkan. Pada akhirnya, mereka bisa menggunakan bahasa inggris dengan baik dan menghasilkan karya yang baik pula.

Sastra dianggap tidak mudah untuk dipelajari, ada pula yang menganggapnya tidak penting karena tidak bisa dipakai dalam kehidupan sehari-hari. Padahal, sastra merupakan cerminan realitas dan darinya kita bisa mengambil pelajaran. Ini sejalan dengan apa yang disebutkan oleh Stanley dalam Tucker (2000):

"reading literature meets personal human needs to impose oneself on the world; or the need to find certainties; or the need to be able to read; or the need to be read; or the need for human acceptance and understanding of all one's pivots and flourishes"

Melalui karya sastra, manusia, khususnya mahasiswa, belajar untuk memahami keadaan dirinya dan memenuhi kebutuhannya sebagai makhluk sosial. Lebih khusus lagi, mahasiswa bisa mengambil pesan moral dan pembelajaran yang bisa mereka 
terapkan nanti ketika lulus dan menjadi pendidik. Mahasiswa bisa menggunakan karya sastra sebagai sumber belajar ketika mereka menjadi pendidik. Sebagai contoh, penggunaan drama untuk meningkatkan ketrampilan berbicara dalam bahasa inggris, pembacaan puisi untuk memperbaiki pelafalan kata bahasa inggris, serta analisis atau pendapat atas karya prosa untuk melatih ketrampilan menulis maupun berbicara.

Mata kuliah kesusastraan diberikan pada program studi yang mempelajari bahasa secara umum, dan sastra secara khusus. Bagi mahasiswa non-sastra, mempelajari sastra merupakan tantangan tersendiri karena mereka dituntut untuk banyak membaca karya dan juga teori yang dipadatkan dalam satu semester. Berbeda dengan mahasiswa sastra, mata kuliah kesusastraan pada mahasiswa non-sastra hanya diberikan pada semester tertentu dan ditempuh dalam dua sks. Permasalahan menjadi lebih kompleks pada mahasiswa yang mengambil pendidikan bahasa Inggris, sebab sebelum mereka bisa memahami isi karya sastra, mereka harus menguasai bahasa yang digunakan. Mereka yang menemukan kesulitan memahami bahasa inggris, akan merasa kesulitan pula memahami makna dan isi karya sastra yang mereka baca, baik pembacaan secara mandiri maupun pembacaan karena tugas.

Pemadatan mata kuliah sastra ini bisa dikatakan tidak cukup. Akan tetapi, karena statusnya bukanlah mata kuliah yang pokok pada jurusan pendidikan bahasa, penambahan mata kuliah tidak bisa dilakukan. Karenanya, mahasiswa sering merasa kesulitan mengikuti mata kuliah kesusastraan. Penulis menemukan komentar ini tertulis pada kolom saran IKD yang harus diisi mahasiswa di akhir semester. Karena sifatnya yang teoritis, para pengampu mata kuliah hanya memberikan ceramah dan meminta mahasiswa melakukan presentasi tentang topik yang dipelajari. Meski diskusi bisa berjalan dengan baik, hasilnya belum memenuhi tujuan yang tercantum dalam silabus atau belum sesuai dengan kapasitas mereka sebagai mahasiswa non-sastra.

Pembelajaran aktif sebagai metode yang disarankan untuk aktifitas belajar mengajar di perguruan tinggi perlu juga diterapkan untuk mata kuliah kesusastraan ini. pembelajaran yang terpusat pada guru telah bergeser 
menjadi pembelajaran yang terpusat pada peserta didik. Guru berperan sebagai fasilitator pembelajaran, bukan sebagai pusat ilmu pengetahuan. Pembelajaran yang terpusat pada guru memiliki kecenderungan menimbulkan kebosanan pada peserta didik karena mereka hanya mendengarkan materi yang disampaikan dengan metode ceramah. Penerapan pembelajaran aktif akan mempertahankan ketertarikan mahasiswa pada perkuliahan dan juga membantu mereka memahami materi yang diberikan. Dengan demikian, penulis mencari tahu bagaimana tanggapan mahasiswa terhadap penerapan metode pembelajaran aktif, khususnya metode pembelajaran kooperatif pada salah satu mata kuliah kesusastraan, yaitu mata kuliah Drama Prose Poetry.

Dari latar belakang tersebut, maka rumusan masalah penelitian ini adalah bagaimana persepsi mahasiswa terhadap penggunaan pembelajaran aktif menggunakan metode pembelajaran kooperatif pada mata kuliah Drama, Prose, Poetry.

Menurut Kamus Besar Bahasa Indonesia Dalam Jaringan (KBBI Daring), persepsi berarti tanggapan (penerimaan) langsung dari sesuatu; serapan. Kamus ini juga memberikan pengertian persepsi sebagai proses seseorang mengetahui beberapa hal melalui pancaindranya. Altman (1985) mengemukakan bahwa persepsi adalah cara seseorang memilih dan mengelompokkan rangsangan untuk memaknainya. Persepsi merupakan cara pandang seseorang terhadap realita. Proses persepsi memungkinkan kita untuk memahami dan menghadapi lingkungan tempat tinggal.

Pembelajaran aktif merupakan pembelajaran yang menuntut peserta didiknya untuk berperan aktif dalam proses kegiatan belajar. Rosyada dalam Nurhayati (2008) dalam Riadi menyatakan bahwa pembelajaran aktif adalah belajar yang memperbanyak aktivitas siswa dalam mengakses berbagai informasi dari berbagai sumber untuk dibahas dalam proses pembelajaran dalam kelas sehingga memperoleh pengalaman yang tidak saja menambah pengetahuan, tapi juga kemampuan analisis dan sintesis (http://www.kajianpustaka.com/2012/12/p embelajaran-aktif.html (diunduh 27 Februari 2016)

Esti Ismawati dalam bukunya Pengajaran Sastra menyebutkan bahwa 
metode kooperatif berfokus pada pengelompokan kecil siswa untuk bekerja sama dalam mencapai tujuan pembelajaran (2013, h. 57). Pembelajaran kooperatif bisa meningkatkan kemampuan sosial peserta didik secara umum. Dengan pembelajaran kooperatif, mahasiswa akan berinteraksi dengan teman-teman satu kelompok untuk mendiskusikan topic yang diberikan. Selain itu, mereka juga akan belajar mendengar, memahami, dan menerima pendapat orang lain. Dengan kata lain, mereka tidak bertindak dan mengambil kesimpulan seorang diri.

Pembelajaran aktif bisa dilakukan dalam beberapa model. Menurut Sri Tutur Martaningsih dkk, dalam Modul Pelatihan Active Learning for Higher Education (ALFHE), ada tiga model pembelajaran aktif yang bisa dilaksanakan di perguruan tinggi.

1. Model pembelajaran langsung, yang di dalamnya pendidik bertindak langsung sebagai model.

2. Model pembelajaran kooperatif, yang dilakukan dengan membagi peserta didik ke dalam kelompok kecil untuk berdiskusi. Diskusi ini dibimbing oleh pendidik. Peserta didik diharapkan bekerja sama untuk mencapai tujuan yang sama dalam proses ini.

3. Model pembelajaran berbasis masalah, yang di dalamnya peserta didik diberikan masalah autentik dan bermakna hingga bisa melakukan penyelidikan dan menemukan solusi untuk permasalahan yang mereka hadapi.

Penelitian ini menggunakan empat kegiatan pembelajaran aktif di kelas: Gallery walk, Information Gap, Jigsaw, dan Drawing.

Menurut Edel-Malizia (2015) gallery walk merupakan kegiatan pembelajaran aktif yang membuat siswa beranjak dari kursi mereka dan berkeliling kelas pada tempat-tempat yang menampilkan obyek yang berkaitan dengan kegiatan kelas. Selain itu, Gregory dan Kuzmich dalam Dinata (2017) menyebutkan bahwa dalam kegiatan gallery walk, siswa berkeliling kelas melihat gambar, poster, atau bahkan karya mereka, dan kemudian berdiskusi. Diskusi tersebut bisa mencakup penyampaian pendapat, berbagi gagasan, dan bahkan mengklarifikasi apa yang telah disampaikan oleh kelompok lain.

Information gap merupakan kegiatan yang di dalamnya siswa hanya 
memiliki informasi yang terbatas dan mereka ditugasi untuk melengkapi kekosongan yang ada bersama dengan teman sekelas (Richter, 2018). Kegiatannya bisa berupa tanya jawab untuk memahami suatu topic, fenomena, atau konsep sesuai materi yang sedang dipelajari.

Pada intinya, jigsaw merupakan kegiatan melengkapi gambar yang sebelumnya dipecah menjadi beberapa bagian. Menurut Pittman (2018), jigsaw merupakan salah satu kegiatan pembelajaran kooperatif yang di dalamnya siswa menguasai salah satu aspek topik yang sedang dipelajari dan kemudian mengajari teman sekelasnya dalam kelompok-kelompok.

Drawing adalah kegiatan membuat gambar menggunakan pensil atau pena. Dalam psikologi, menggambar digunakan sebagai langkah investigasi untuk mencari bukti yang lebih baik dibandingkan media Bahasa (Puglionesi, 2016). Menggambar memiliki beberapa tujuan, misalnya (Museum London: 2016) memvisualisaikan pikiran dan menyelesaikan suatu permasalahan, serta memberi pola untuk diikuti atau memberi instruksi bagaimana membuat suatu objek.
Penelitian tentang pembelajaran sastra di perguruan tinggi sangat jarang dilakukan, terlebih yang berkaitan dengan pembelajaran aktif. Novianti (2016) dalam artikelnya yang berjudul English Literature Teaching: An Indonesian Context, menyebutkan beberapa strategi untuk menyampaikan materi sastra di tingkat perguruan tinggi. Akan tetapi, yang bersangkutan tidak menyebutkan model pembelajaran yang dipergunakan, melainkan strategi yang diambil oleh pendidik untuk mengatasi permasalahan pengajaran sastra di tingkat perguruan tinggi, misalnya penugasan individual, kelompok membaca, dan penggunaan sumber internet.

Peneliti menemukan beberapa artikel yang berkaitan dengan pembelajaran sastra dan penerapan pembelajaran aktif untuk mata kuliah kesusastraan.

Esti Swatika Sari (2016) menuliskan sebuah artikel berjudul "Mengoptimalkan Kembali LIterasi Sastra di Perguruan TInggi- Perlukah?" Dalam artikelnya, penulis mengkaji tentang perlunya kemampuan membaca dan menulis sastra di perguruan tunggi.

Selain itu, permasalahan pengajaran bahasa dan sastra Inggris di perguruan 
tinggi dibahas oleh Bachrudin Musthafa (2015) dalam artikelnya yang berjudul “Problematika Pengajaran Bahasa dan Sastra Inggris di Perguruan Tinggi di Indonesia." Dia mengemukakan bermacam isu dan dilemma yang dihadapi program studi bahasa dan sastra Inggris di Indonesia dan mengajukan usulan tentang orientasi pengajaran sastra Inggris menuju pengembangan literasi kesusastraan.

Yang terakhir, sebuah artikel yang khusus membahas pembelajaran aktif untuk pengajaran sastra dibahas oleh Diana Presada, Ph.D. dalam artikelnya yang berjudul "Teaching Literature by Means of Games in Higher Education". Dalam artikelnya, Diana memaparkan bahwa penggunaan games atau permainan dalam pembelajaran aktif di perguruan tinggi dianggap tidak tepat untuk pembelajaran sastra. Tetapi dalam penelitiannya, Diana mendapatkan persepsi positif dari peserta didik dan mengemukakan bahwa permainan akan meningkatkan suasana pembelajaran dan mengarahkan peserta didik pada pengembangan kemampuan yang disyaratkan dalam silabus mata kuliah kesusastraan.

\section{Metodologi Penelitian}

Penelitian ini termasuk dalam penelitian survey karena memiliki beberapa karakteristik (Ary dkk dalam Arilia, 2012), misalnya menghasilkan deskripsi dalam angka tentang berbagai aspek populasi yang diteliti dan memiliki pertanyaan yang diajukan sehingga jawabannya bisa digunakan sebagai data untuk dianalisis.

Metode survey digunakan karena yang diteliti adalah persepsi mahasiswa terhadap penerapan pembelajaran aktif dalam mata kuliah Drama Prose Poetry. Data yang diperoleh adalah data kualitatif dan data kuantitatif. Data kualitatif dihasilkan dari kuesioner terbuka dan data kuantitatif dihasilkan dari kuesioner tertutup.

Populasi dalam penelitian ini adalah mahasiswa semester empat $\mathrm{PBI}$ UAD tahun ajaran 2016/2017. Sampel yang dilibatkan adalah 80 mahasiswa dari dua kelas yang berbeda yang mengambil mata kuliah Drama Prose Poetry yang diampu oleh peneliti. Penelitian ini akan mengkaji dan menganalisis persepsi mahasiswa terhadap penerapan pembelajaran aktif menggunakan model pembelajaran kooperatif pada mata kuliah Drama Prose Poetry. 
Instrumen yang digunakan dalam penelitian ini adalah kuesioner terbuka dan tertutup. Kedua kuesioner ini digunakan untuk mengumpulkan data kualitatif dan kuantitatif tentang persepsi mahasiswa $\mathrm{PBI}$ terhadap penerapan pembelajaran aktif pada mata kuliah Drama, Prose, Poetry. Kuesioner ini dibagikan kepada mahasiswa semester empat PBI UNiversitas Ahmad Dahlan yang mengambil mata kuliah Drama Prose Poetry, khususnya dua kelas yang diampu peneliti.

Data dari kuesioner dikumpulkan untuk mengetahui persepsi mahasiswa terhadap penerapan pembelajaran aktif. Setelah mendapatkan data dari kuesioner, data akan diklasifikasikan dan direkap dalam bentuk prosentase. Data dari kuesioner kemudian dianalisis dengan melihat serta menghitung prosentasenya. Data kuesioner dimasukkan dalam tabel yang terdiri atas kolom pernyataan dan kolom jumlah mahasiswa yang memilih opsi tertentu. Analisis ini bertujuan untuk mengetahui persepsi mahasiswa semester empat terhadap penerapan pembelajaran aktif. Dari hasil analisis akan diketahui apakah mahasiswa mempunyai persepsi yang positif atau negatif terhadap penerapan pembelajaran aktif pada mata kuliah Drama Prose Poetry.

\section{Hasil dan Pembahasan}

Pada sub-bab ini peneliti menampilkan hasil kuesioner tertutup dan terbuka untuk mendapatkan data tentang persepsi mahasiswa terhadap penggunaan pembelajaran aktif pada mata kuliah Drama Prose Poetry.

Kuesioner tertutup berisi 7 pertanyaan pilihan ganda dengan hasil berupa angka yang mencerminkan pilihan responden untuk pertanyaanpertanyaan yang diberikan. Empat dari tujuh pertanyaan yang diberikan mendapatkan jawaban yang tidak valid. Artinya, ada responden yang tidak menjawab pertanyaan tersebut, ataupun memilih lebih dari satu jawaban. Setiap pertanyaan yang diajukan hanya memiliki satu jawaban saja.

a.Pertanyaan 1 (Mana yang lebih Anda sukai?).

Pertanyaan ini mengacu pada dua tipe utama proses pembelajaran, yakni berpusat pada dosen dan berpusat pada mahasiswa. Pilihan pertama menunjukkan student-centered learning sedang yang kedua menunjukkan teacher-centered learning. 
Tabel 1. Hasil jawaban responden atas Pertanyaan 1

\begin{tabular}{|l|c|}
\hline Mahasiswa Aktif belajar di kelas & 58 \\
\hline $\begin{array}{l}\text { Dosen menerangkan dari awal } \\
\text { hingga akhir perkuliahan }\end{array}$ & 14 \\
\hline Tidak valid & 1 \\
\hline Total & 83 \\
\hline
\end{tabular}

Sumber: Data penelitian, 2017

b. Pertanyaan 2 (Di antara kegiatan berikut, mana yang lebih Anda sukai?)

Tabel 2. Hasil jawaban responden atas pertanyaan 2

\begin{tabular}{|l|l|}
\hline Gallery walk (mengetahui jalan cerita & 53
\end{tabular} karya drama melalui gambar)

Jigsaw (Mengetahui detail karya 6 drama melalui isian table)

Drawing (Mengetahui ide pokok 19 sebuah cerita pendek melalui gambar)

Information gap (Mengetahui 4 pemilihan kata yang tepat dalam sebuah puisi)

Tidak valid

Total

(Sumber: Data penelitian, 2017)

c. Pertanyaan 3 (Apakah kegiatan pada nomor 2 membantu Anda memahami isi materi perkuliahan Drama Prose Poetry?

Pertanyaan 3 ini berkaitan dengan pertanyaan nomor 2 tentang kegiatan pembelajaran yang telah dilaksanakan. Pertanyaan ini dimaksudkan untuk melihat persepsi responden terhadap kegiatan yang disebutkan pada pertanyaan 2.
Tabel 3. Hasil jawaban responden atas pertanyaan 3

\begin{tabular}{|l|c|}
\hline Sangat membantu & 35 \\
\hline Cukup membantu & 47 \\
\hline Kurang membantu & 1 \\
\hline Sangat tidak membantu & 0 \\
\hline Tidak valid & 0 \\
\hline Total & 83 \\
\hline
\end{tabular}

(Sumber: Data penelitian, 2017)

d. Pertanyaan 4 (Apakah dosen menerangkan dengan jelas apa yang harus dilakukan sebelum melakukan kegiatan pada nomor 2?)

Tabel 4. Hasil jawaban responden atas pertanyaan 4

\begin{tabular}{|l|c|}
\hline Sangat jelas & 37 \\
\hline Cukup jelas & 43 \\
\hline Kurang jelas & 2 \\
\hline Sangat tidak jelas & 1 \\
\hline Tidak valid & 0 \\
\hline Total & 83 \\
\hline
\end{tabular}

e. Pertanyaan 5 (Apakah variasi kegiatan di kelas bisa menghindarkan kebosanan?)

Tabel 5. Hasil jawaban responden atas pertanyaan 5

\begin{tabular}{|l|c|}
\hline Ya & 76 \\
\hline Tidak & 6 \\
\hline Tidak valid & 1 \\
\hline Total & 83 \\
\hline
\end{tabular}

(Sumber: Sumber data, 2017)

f. Pertanyaan 6 (Apakah Anda lebih mudah mengingat pengarang atau karya sastra melalui kegiatan nomor 2?) 
Tabel 6. Hasil jawaban responden atas pertanyaan 6

\begin{tabular}{|l|c|}
\hline Ya & 71 \\
\hline Tidak & 11 \\
\hline Tidak valid & 1 \\
\hline Total & 83 \\
\hline
\end{tabular}

(Sumber: Data penelitian, 2017)

g. Pertanyaan 7 (Apakah menurut Anda kegiatan nomor 2 memakan waktu dan tidak ada manfaatnya?)

Tabel 7. Hasil jawaban responden atas pertanyaan 7

\begin{tabular}{|l|l|}
\hline Ya & 3 \\
\hline Tidak & 80 \\
\hline Tidak valid & 0 \\
\hline Total & 83 \\
\hline
\end{tabular}

(Sumber: Data penelitian, 2017)

Selain kuesioner tertutup, penelitian ini juga menggunakan kuesioner terbuka yang terdiri dari empat pertanyaan yang mewakili kesan dan rekomendasi dari responden untuk kegiatan pembelajaran Drama Prose Poetry di tahun ajaran selanjutnya. Keempat pertanyaan tersebut memiliki jawaban yang bervariasi dan peneliti mengelompokkan bermacam jawaban yang serupa.

a. Pertanyaan 1 (Bagaimana pendapat Anda terhadap penerapan pembelajaran aktif yang sudah dilaksanakan pada perkuliahan Drama Prose Poetry?) b. Pertanyaan 2 (Menurut Pendapat Anda, apa kekurangan dari kegiatan pembelajaran aktif yang sudah dijalankan di kelas (Gallery Walk, Jigsaw, Drawing, Information Gap?)

c. Pertanyaan 3 (Menurut Anda, apakah mahasiswa $\mathrm{PBI}$ perlu mempelajarai karya sastra? Mengapa?)

d. Pertanyan 4 (Menurut Anda, kegiatan seperti apa yang Anda sarankan untuk mempermudah mahasiswa memahami karya sastra?)

Jawaban dari pertanyaan kuesioner terbuka ini dipakai sebagai data pendukung.

Persepsi Mahasiswa terhadap Pembelajaran Aktif pada mata kuliah

\section{Drama Prose Poetry}

Seperti yang disebutkan Esti Ismawati (2013), metode kooperatif mengedepankan kegiatan diskusi berkelompok untuk menyelesaikan suatu permasalahan. Untuk meningkatkan kemampuan sosial peserta didik, pembelajaran aktif dilaksanakan di kelas mata kuliah Drama, Prose, Poetry.

Dari hasil kuesioner, ditemukan bahwa separuh dari jumlah responden memiliki persepsi yang positif atas penggunaan metode pembelajaran 
kooperatif di dalam kelas seperti yang dijelaskan di bawah.

a. Mahasiswa lebih suka aktif belajar di kelas

Materi pada mata kuliah kesusastraan pada program studi non-sastra cenderung disampaikan dengan metode ceramah. Dosen menjelaskan dan mahasiswa mendengarkan. Mahasiswa hanya sesekali bertanya atau menjawab pertanyaan. Yang sering terjadi, mahasiswa tidak berkeinginan untuk bertanya karena ingin perkuliahan cepat selesai atau mereka belum paham apa yang disampaikan oleh dosen.

Ketika diberi pilihan antara mendengarkan dosen menjelaskan dan belajar aktif di kelas, lebih dari separuh jumlah responden (53) menjawab bahwa mereka lebih suka aktif belajar di kelas. Hal ini dikuatkan dengan pernyataan mereka pada pertanyaan terbuka nomor 1. Beberapa jawaban tersebut di antaranya:

(1) "sangat bagus karena jika hanya mendengar saja mahasiswa akan semakin pasif"
(2) "cukup membantu, membuat mahasiswa ikut berpartisipasi jadi tidak hanya mendenggarkan dosen saja"

(3) "sangat membantu karena semua mahsaiswa aktif dalam memahami mata kuliah Drama Prose Poetry, dan dapat dengan mudah mahasiswa bekerja sama dengan kelompok"

Meski demikian, ada responden yang memilih jawaban b (Dosen menerangkan dari awal hingga akhir perkuliahan.) Akan tetapi dari semua jawaban pada kuesioner terbuka, tidak ditemukan jawaban yang mendukung.

Pembelajaran aktif di kelas bisa menjadi pilihan untuk menghindarkan kejenuhan mahasiswa, terutama dalam mengikuti perkuliahan dengan materi kesastraan. Mahasiswa Pendidikan Bahasa Inggris bisa mengambil lebih banyak manfaat melalui pembelajaran aktif. Mereka juga bisa mengungkapkan gagasan mereka melalui beberapa kegiatan yang dilakukan di dalam dan di luar kelas. 
b. Mahasiswa lebih menyukai Gallery Walk

Ada empat kegiatan yang diterapkan dalam pembelajaran:

(1) Gallery walk

Dalam kegiatan ini, mahasiswa

belajar memahami runtutan

adegan karya drama melalui

gambar. Mahasiswa bekerja

dalam kelompok kecil dan

mereka menggambar sebuah latar pada sebuah kertas berukuran $\mathrm{A} 3$. Kemudian gambar-gambar tersebut dipampang di dinding di dalam kelas. Setiap kelompok memilih salah satu anggota untuk menjadi pemandu gambar mereka dan yang lain diberi tugas untuk berkeliling melihat gambar kelompok lain. Yang bertugas di tempat berkewajiban menerangkan adegan kepada mahasiswa lain yang berkunjung ke tempat gambar mereka ditempel.

Kegiatan gallery walk membutuhkan lebih banyak persiapan dari sisi mahasiswa. Agar pembelajaran berjalan lancar, mereka sudah harus mempersiapkan poster dari rumah. Ketika di kelas, mereka hanya perlu menempel gambar di dinding. Kendala kegiatan ini adalah ada beberapa kelompok yang belum menyelesaikan gambar. Selain itu, ada kelompok yang anggotanya bertugas membawa gambar tidak masuk, sehingga mereka harus menggambar ulang. Gambar-gambar yang menarik mendapatkan lebih banyak pengunjung dibandingkan dengan gambar yang ala kadarnya dan tidak maksimal.

Kegiatan ini bisa melatih ketrampilan membaca, mendnegarkan, dan berbicara. Untuk dapat menggambarkan latar adegan, mahasiswa harus bisa membaca naskah dengan baik dan memahaminya. Setelah mereka menggambarkannya, mereka belajar menyampaikan adegan sesuai gambar dalam bahasa Inggris. Bagi 'pengunjung' kegiatan ini melatih ketrampilan menyimak karena mereka mendengarkan 
penjelasan dari pemandu setiap gambar yang mereka lihat.

Cara ini mempermudah mahasiswa mengenali beberapa karya sekaligus. Dengan gambar dan sedikit penjelasan, cerita atau latar karya drama lebih mudah dipahami. Dan karena sifatnya tidak duduk di tempat, mahasiswa merasa lebih santai dalam mengikuti pembelajaran. Perasaan yang tenang dan tidak tegang mempermudah penyampaian dan pemahaman materi, terutama karya sastra drama.

(2) Jigsaw

Jigsaw merupakan kegiatan melengkapi tabel keterangan untuk karya drama yang telah dibaca secara berkelompok. Dalam kegiatan ini, mahasiswa diharuskan sudah membaca karya yang dipilih sebelum pembelajaran dimulai karena mereka akan menjelaskan unsurunsur intrinsic karya drama pada anggota kelompok lain. Di kelas, para mahasiswa diminta bertukar tempat sehingga mereka bekerja dengan kelompok lain. Mereka harus melengkapi tabel yang berisikan unsur-unsur intrinsik karya, seperti judul, nama pengarang, tokoh yang ada dalam cerita, plot, serta latar. Mahasiswa yang telah membaca karyanya dengan baik akan bisa memberikan informasi yang lengkap. Sebaliknya, mereka yang belum membaca akan menyulitkan rekan kerjanya karena mereka tidak tahu tentang karya tersebut.

Kendala kegiatan ini adalah adanya mahasiswa yang belum membaca karya, sehingga mereka harus membaca kembali ketika kegiatan berlangsung. Ini menghambat pengumpulan hasil oleh kelompok pendengar sehingga tabel yang harus mereka isi tidak bisa mereka lengkapi dengan baik.

(3) Drawing

Kegiatan drawing atau menggambar ini berupa kegiatan menyimpulkan tema sebuah karya prosa melalui gambar. Mahasiswa membaca karya tersebut kemudian 
mereka akan bisa menyebutkan tema apa yang terkandung dalam karya tersebut. Dalam kegiatan ini, mahasiswa juga bekerja dalam kelompokkelompok kecil dan mereka akan mendiskusikan tema apa yang disampaikan oleh karya yang mereka baca. Kesulitan mahasiswa pada kegiatan ini adalah ketidakmampuan beberapa dari mereka untuk menggambar. Dengan kata lain, mereka bisa menyimpulkan tema dengan baik secara lisan tetapi ketika menuangkan dalam gambar mereka mengalami kendala.

(4) Information Gap Kegiatan yang terakhir ini merupakan kegiatan yang bertujuan untuk membantu mahasiswa memahami karya puisi. Sebelum pertemuan, mahasiswa dan kelompoknya membaca sebuah karya puisi yang sudah dipilih. Kemudian peneliti mengedarkan lembar puisi yang sudah dikosongi beberapa katanya. Mereka berdiskusi melengkapi puisi tersebut.

Dalam kegiatan ini, dosen harus memastikan bahwa mereka tidak mendapatkan puisi yang sudah dipilih oleh kelompoknya. Ketika memilih kata untuk melengkapi baris-baris dalam puisi, mahasiswa mengeksplorasi pelafalan kata dan bunyi. Jika mereka bisa menebak pola bunyi dan makna setiap bait yang mereka baca, mereka akan memilih jawaban yang benar. Setelah terisi semua, mereka akan memahami dua hal: karya sastra secara utuh dan pola bahasa yang digunakan dalam karya sastra puisi.

Di akhir semester, mahasiswa diminta membuat puisi mereka sendiri untuk dibacakan di depan kelas. Setelah memahami beberapa puisi dari pertmuan dan kegiatan information gap, mahasiswa bisa meniru pola dan makna. Ini melatih kreatifitas dan daya rasa mahasiswa terhadap puisi. Ini juga sekaligus mengasah kemampuan bahasa 
inggris dan menggali lagi emosi

yang mereka miliki.

Di antara keempat kegiatan ini, hampir seluruh responden memilih kegiatan gallery walk (53 responden), diikuti drawing (19), information gap (6), dan poetry jigsaw (4). Gallery walk memberikan kesempatan pada mahasiswa untuk berkreasi dengan imajinasi dan gambar. Pada prosesnya, responden juga merasakan kegiatan yang lebih santai dengan berjalan-jalan seperti di dalam museum, tidak seperti pembelajaran yang monoton. Dalam kegiatan ini, mahasiswa mempelajari karya sastra dari kelompok-kelompok lain dengan cara yang berbeda, bukan hanya dari dosen yang menceritakan jalan cerita sebuah karya dari awal hingga akhir pertemuan.

c. Mahasiswa merasa terbantu memahami isi materi perkuliahan Drama Prose Poetry melalui pembelajaran kooperatif.

Hampir semua responden (82) menjawab bahwa kegiatan yang disebutkan di atas membantu mereka memahami isi materi perkuliahan Drama Prose Poetry. Pembelajaran ini memberi kesempatan pada peserta didik untuk berpartisipasi dalam kegiatan kelas. Dengan berpartisipasi, sumber pengetahuan dan pengalaman tidak hanya berasal dari dosen tetapi dari teman sekelas dan bahkan diri mereka sendiri. Hal ini ditunjukkan dengan pendapat responden atas pertanyaan kuesioner terbuka nomor 1 (Bagaimana pendapat ANda terhadap penerapan pembelajaran aktif yang sudah dilaksanakan pada pada perkuliahan Drama Prose Poetry?), misalnya:

(1) Bagus, karena mahasiswa dapat mengetahui sendiri apa yang dipelajari (D-11)

(2) Menurut saya dnegan belajar aktif akan menangkap materi dengan mudah dan paham (A42)

(3) Penerapan pembelajaran aktif dapat membantu mahasiswa untuk memahami materi yang diebrikan dosen, tetapi dosen tetap harus memantau dan mengarahkan para mahasiswa (D-3) 
Pendapat nomor 3 ini sekaligus memberikan saran pada dosen untuk tetap aktif memantau meski tidak menjadi pusat pembelajaran.

d. Instruksi yang dijelaskan dosen sebelum memulai kegiatan pembelajaran aktif.

Berkaitan dengan cara dosen menyampaikan instruksi, sebagian besar mahasiswa menjawab a (sangat membantu) dan b (cukup membantu). Hal ini diperkuat dengan jawaban pada kuesioner terbuka, misalnya: "Dosen dalam memberikan instruksi kurang jelas dan kurang detail". Akan tetapi, kekurnagan yang ada dalam pelaksanaan pembelajaran aktif lebih disebabkan oleh mahasiswa. Hal ini dinyatakan dalam jawaban responden, di antaranya:

(1) “Ada beberapa anak yang pasif dan hanya melihat-lihat atau mengikuti temannya saja, jadi tidak semua anak memahami cerita"

(2) "keadaan kelas kurang kondusif, ramai"

(3) "mahasiswa kurang aktif berekspresi di kelas"
(4) "suasana kelas yang kurang kondusif, mahasiswa sibuk dengan kegiatan masingmasing"

Ini menunjukkan bahwa untuk melaksanakan pembelajaran aktif, dosen dan mahasiswa perlu melakukan persiapan yang memadai. Dosen harus mengantisipasi kemungkinan ada mahasiswa yang pasif. Pembelajaran aktif memerlukan persiapan yang lebih karena kketerlibatan mahasiswa menentukan sukses tidaknya kegiatan yang direncanakan.

e. Kegiatan yang bervariasi menghindarkan kebosanan

Dari pertanyaan kuesioner tertutup no 5, sebagian besar responden (76) memilih jawaban ya. Ini berarti bahwa responden merasa kegiatan di kelas bisa menghindarkan kebosanan: "Penerapan belajar yang aktif karna model pembelajarannya yang digunakan sangat bervariasi sehingga tidak saja monoton dan membosankan, namun menjadi mudah untuk dipahami" (D-15). Responden lain juga menyatakan 
bahwa model ini cukup menarik dan membuat mereka merasa antusias. (D-16).

Dari semua kuesioner, ditemukan satu jawaban yang menerangkan manfaat pembelajaran kooperatif:

"Menurut saya, pembelajaran aktif ini sangat menyenangkan karena kita dibagi menjadi beberapa kelompok dan bisa bekerja sama satu dengan yang lainnya. Dan saya suka jika terlibat dengan orang banyak." (D-38)

Pembelajaran aktif melatih kemampuan sosial mahasiswa. Sebelum, ketika, dan setelah melakukan pembelajaran, mereka harus berinteraksi satu sama lain, bekerja sama menyelesaikan tugas dan mempersiapkan materi untuk dipresentasikan.

Dari beberapa kelompok yang mengerjakan tugas, peneliti menemukan satu kelompok yang mengalami kendala dalam pengerjaan gambar untuk gallery walk. Para anggota kelompok ini memiliki persepsi yang berbeda terhadap jalan cerita dari rangkaian adegan yang mereka baca. Mereka tetap memiliki gambar untuk dipresentasikan tetapi terlihat sekali bahwa mereka tidak sepakat satiu sama lain.

f. Mahasiswa lebih mudah mengingat pengarang atau karya sastra melalui bermacam kegiatan pembelajaran aktif.

Sebagian besar mahasiswa menjawab bahwa kegiatan ini membuat mereka lebih mudah mengingat pengarang atau karya sastra. Drama Prose Poetry menawarkan begitu banyak karya sastra dan pengarangnya. Mahasiswa dari kedua kelas dibagi dalam kelompok kecil dan masingmasing harus memilih satu dari enam belas judul karya yang diberikan dalam tiap genre. Dengan demikian, satu kelompok akan membaca satu karya drama, satu karya prosa, dan satu karya puisi. Kegiatan pembelajaran aktif yang dilakukan mempermudah mahasiswa mengingat karya sastra yang mereka baca beserta pengarangnya: 


"Proses belajar menjadi
lebih menarik, sehingga
mahasiswa dapat mempelajari
materi secara sempurna,
mengingat dan dapat
menjelaskan dengan mudah..."

Dengan metode ceramah, banyak informasi yang diberikan oleh dosen. Akan tetapi, metode ceramah tidak efektif untuk membuat mahasiswa mengingat karya ataupun pengarangnya. Dengan melakukan pembelajaran aktif, pengetahuan yang merkea dapatkan akan lebih berkesan dan melekat dalam ingatan.

g. Bermacam kegiatan pembelajaran aktif tidak dianggap memakan waktu

Meski hampir semua jawaban responden menunjukkan bahwa kegiatan pembelajaran aktif tidak memakan waktu, namun hal yang sebaliknya terungkap dalam pertanyaan kuesioner terbuka, terutama yang berkaitan dengan kekurangan kegiatan pembelajaran aktif:

(1) Gallery walk: (a) Membutuhkan waktu yang lebih untuk mempersiapkan gallery yang menarik (D-17)

(b) Ramai, tidak kondusif, mahasiswa bergerombol (D31)

(c) Dalam beberapa sesi kurang efektif, seperti gallery walk, kurang memahami secara penuh karya teman (D-16)

(d) Terlalu banyak waktu yang terbuang (D-26)

(2) Drawing:

(a) Bagi mahasiswa yang tidak bisa menggambar yang bagus, sedikit sulit untuk mengaplikasikan ide ke dalam media gambar tersebut (D-17)

(b) Mungkin jika menggambar akan memakan banyak waktu dan tidak semua orang dapat menggambar $(\mathrm{A}-9)$

Dari semua kekurangan yang disebutkan, tidak ada yang berkaitan dengan kebermanfaatan kegiatan pembelajaran aktif. Meski secara terbuka responden menyatakan kegiatan ini memakan waktu, tapi tidak ditemukan data yang menyebutkan bahwa kegiatan 
yang dilakukan tersebut tidak bermanfaat.

Persepsi positif mahasiswa terhadap penerapan pembelajaran aktif menggunakan metode kooperatif membantu mahasiswa memahami karya sastra dan melatih kemampuan sosial mereka. Meski terlibat konflik antara sessama anggota, mereka tidak mengalami kendala dalam menjelaskan karya yang mereka telah baca.

\section{Kesimpulan}

Dari penelitian yang telah dilakukan, terlihat bahwa mahasiswa memliki persepsi yang positif terhadap penerapan pembelajaran aktif, terutama pembelajaran kooperatif dengan gallery walk, information gap, jigsaw, dan drawing picture. Sebagian besar mahasiswa berpendapat bahwa kegiatan yang aktif membuat mereka lebih memahami materi yang disampaikan dan menghindarkan kebosanan. Banyaknya pengarang sastra dan karya yang dihasilkan juga lebih mudah diingat melalui kegiatan aktif ini.

Penelitian terhadap persepsi mahasiswa PBI terhadap pembelajaran aktif model pembelajaran kooperatif memiliki kelebihan dan kekurangan.
Responden memberikan saran-saran kegiatan yang bisa diterapkan untuk mempelajari karya sastra. Pertama menyampaikan materi melalui media gambar, video, dan audio. Berkunjung ke museum atau menonton pertunjukan sastra juga bisa menjadi alternative pembelajaran. Mahasiswa juga akan lebih tertantang dengan mempraktikan atau mementaskan salah satu karya. Saran-saran tersebut bisa menjadi dasar untuk melakukan penelitian lanjutan, seperti pengembangan metode pembelajaran atau pengembangan materi ajar.

Penggunaan karya sastra asing bisa menjadi alternative meningkatkan kompetensi bahasa asing mahasiswa, terutama bahasa Inggris. Ada beberapa kegiatan yang bisa dilakukan penelitipeneliti lainnya. Misalnya, mereka bisa menggunakan karya-karya dalam penelitian ini untuk melatih ketrampilan berbicara peserta didik. Pembacaan karya sastra prosa juga bisa dilakukan karena bisa melatih kepercayaan diri peserta didik di depan kelas. Selain itu, penulisan laporan buku juga bisa mengajsah kerampilan menulis mahasiswa. Sementara untuk karya puisi, mahasiswa bisa menggali kumpulan 
kosakata bahasa Inggris yang mereka

miliki untuk membuat puisi. Pembacaan

puisi akan melatih mereka melafalkan

kata-kata baru dengan baik dan benar.

Kata yang diucapkan dengan baik dan

benar akan memberikan kemudahan

pendengar memahami apa yang

disampaikan.

\section{Daftar Pustaka}

Altman, S, et.al. (1985). Organizational Behaviour: Theory and Practice. Florida Academic Press, Inc.

Dinata, H. (2017)"THE USE OF GALLERY WALK TOO ENHANCE THE SPEAKING ACHIEVEMENT OF THE NINTH GRADE STUDENTS OF SMP PGRI 1PALEMBANG." Jurnal Global Expert 6.1

Edel, S, et.al. (2015). Pedagogical PraticesGallery Walk. (https://scholarsphere.psu.edu/downlo ads/1jw827964s

Ismawati, E. (2013). Pengajaran Sastra. Yogyakarta: Penerbit Ombak.

Novianti, N. (2016). "English Literature Teaching: an Indonesian Context." Indonesian Journal of Applied Linguistics 6.1: 42-49.

Presada, D. (2015). Teaching Literature By Means of Games in Higher Education. Journal Plus Education ISSN: 1842-077X Vol XII No. 2.

Pittman, M. (2018). How to Use the Jigsaw Strategy with Your Students. https://support.newsela.com/hc/enus/articles/214902046-How-to-use-thejigsaw-strategy-with-your-students

Puglionesi, A. (2016). "Drawing as Instrument, Drawings as Evidence: Capturing Mental Processes with Pencil and Paper." An International Hournal for the History of Medicine and Related Sciences. July: 359-387. Doi: 10.1017/mdh.2016.28

Martaningsih et. al, Sri Tutur. (2015). Modul Pelatihan Active Learning for Higher Education (ALFHE). Yogyakarta.
Riadi, Muhsin. (2016). Pengertian Pembelajaran Aktif. http://www.kajianpustaka.com/2012/12 /pembelajaran-aktif.html (diunduh pada 27 Februari, 2016)

Richter, J. (2018). https://study.com/academy/lesson/info rmation-gap-activity-definitionstrategy.html

Şengül, S, \& Yasemin, K. (2014) Effects of jigsaw technique on mathematics selfefficacy perceptions of seventh grade primary school students. ProcediaSocial and Behavioral Sciences 116: 333338.

Triyoga, A. (2015). Persepsi Mahasiswa Kelas Pre-Intermediate Structure PBI UAD Terhadap Penerapan Mobile Learning. Yogyakarta: UAD.

Tucker, L. P. (2000). Liberating Students through Reader-Response Pedagogy in the Introductory Literature Course. Desember 2000, National Council of Teacher of English. TETYC: 199-206.

Victoria and Albert Museum. 2016. http://www.vam.ac.uk/content/articles /w/what-is-drawing/ https://www.teachingenglish.org.uk/ar ticle/information-gap 